\title{
Transformation Of Social And Economic Livelihoods Of Rubber Farmers
}

\section{Ecces: Economics Social and Development Studies}

\author{
Fajrin Kasdi ${ }^{1}$ \\ Department of Economics, Faculty of Economics and Islamic Business, \\ UIN Alauddin Makassar, Indonesia ${ }^{1}$ \\ e-mail: fajrinkasdi.economics@gmail.com
}

(Article history) Received: 2020-12-10, Revised: 2020-12-24, Accepted: 2020-12-25,

Available online: 2020-12-26, DOI: https://doi.org/10.24252/ecc.v7i2.16286

http://journal.uin-alauddin.ac.id/index.php/ecc/index

\section{Abstract: Transformation Of Social And Economic Livelihoods Of Rubber Farmers}

Rubber production in Bulukumba Regency continues to increase the amount of production every year, to be precise in Bulukumpa District, Batulohe Village. But in fact, the life of rubber farmers is still very far from prosperous. The novelty of this research is to try to capture the livelihoods of rubber farmers from sociological and economic aspects. The purpose of this study was to determine the structure of land tenure, wage levels, education levels, access to information, and trade value chains in Batulohe Village, Bulukumpa District. This research was conducted in Batulohe Village, Bulukumpa District, Bulukumba Regency. This type of research is qualitative ethnographic in nature, this model seeks to study cultural events, which present the subject's view of life as an object of study. The data source of this research comes from direct interviews with rubber farmers. Data processing and data validation techniques used were source triangulation techniques to test the validity of the information obtained from informants. The results showed that there was no imbalance in land tenure structure because in fact the community already owned land. The level of wages given to farm laborers is not proportional because it does not follow the prevailing rubber price trend. The education level of farmers is still relatively low. Meanwhile, existing access to information is not transparent and unequal because it is monopolized by traders at both the village and city levels. Finally, the trade chain that occurs involves several actors, starting from farmers, village traders, urban traders to the processing industry, which tends not to benefit farmers. A big push intervention policy from the government is needed so that there will be a redistribution of fiscal allocations to the poor and an improvement in livelihoods and income.

Keywords: Rubber Farmers, Social Economic; Welfare. 


\section{INTRODUCTION}

South Sulawesi Province, to be precise in Bulukumba Regency, is a leading area in the rubber plantation sector. This is evident from the data that shows an increase in the amount of production each year, from 2,013 tons in 2011 and in 2019 it has increased again to 3,990 tons (BPS Kabupaten Bulukumba, 2020). An increasing trend such as the data above should have a positive correlation with the welfare of rubber farmers. However, the fact is, on the contrary, the life of rubber farmers in Bulukumba Regency, especially in Bulukumpa District, is still very far from prosperous. In line with Khairil and Faisal's research (2019), it was found that there was environmental damage, resulting in the loss of people's livelihoods and a decrease in income. Modernization of development to rural areas triggers capitalization and does not improve farmers' livelihoods (Webb, 2015). Data from the Bulukumba Central Bureau of Statistics (BPS) in 2019 placed Bulukumpa District as the area with the poorest population (6,309 people), followed by Kajang District (6,109 people) and the third was Gantarang District (6,009 people). The data above affirms the existence of such a complex problem and must be resolved in an appropriate and measured way (BPS Kabupaten Bulukumba, 2019).

Batulohe Village is part of the Bulukumpa District which is the center for smallholder rubber production. On average, people work as rubber farmers, because they are considered a promising commodity. The results of field observations show that rubber farmers are facing various kinds of problems, one of which is wages and access to information. Batulohe Village provides hope for improving livelihoods for rubber farmers so that continuous and accelerated efforts are needed to achieve this goal. Rubber plantations provide a very large economic dimension, especially to the rural economy. The ability to absorb labor will increase income because basic income is a measure of the level of welfare of the community, especially rural areas in reducing the level of poverty (Erwin, 2014).

The existence of plantations is not only limited to earning foreign exchange but plays a role in providing employment opportunities for the surrounding communities and directly supporting community economic development. The agricultural sector produces various consumer products and raw materials for the industrial sector (agro-industry), while the industrial sector produces various needs for the agricultural sector. The existence of a relationship between one sector and another and this relationship increases in line with the current economic growth that occurs in the sector which will hamper the growth of the industrial sector, especially agro-industry due to the delay in the flow of raw materials from 


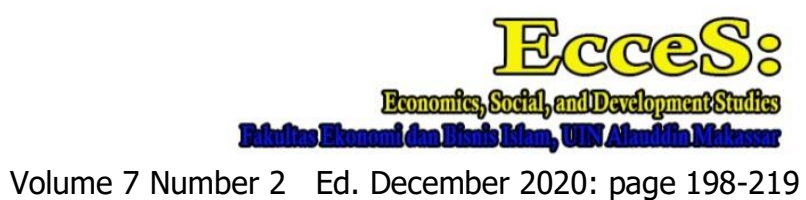
p-ISSN: 2407-6635 e-ISSN : 2580-5570

agriculture which is needed. The benefit of increasing one's income will create prosperity, either from the transfer of production factors or after carrying out economic activity. With high enough economic growth, it is able to provide more job opportunities so that people's welfare can increase.

Economic growth is absolutely necessary to be increased because high economic growth means that the level of people's welfare is increasing. Likewise, the government is always trying to increase regional economic growth. The factors that affect economic growth in an area include Human Resources (HR), Natural Resources (SDA), factors in the development of science and technology. These four factors play an important role in economic growth and can increase the production of rubber plantations. Of these four factors, the community implements a strategy in developing natural resources so that they can be managed properly and can provide income for the whole community, including the farming community. Because basically the management of natural resources properly can meet the necessities of life, both food and clothing needs, and shelter. In addition to fulfilling needs, it will also increase income through rubber production (Asrina, 2013).

Based on the observations that have been made, the researcher found that there are many problems being faced by rubber farmers, from wages to farm laborers to production which is sometimes not as desired due to unfavorable weather. As stated by one of the interviewees.

"Usually during the rainy season the price of rubber goes down because a lot of rubber is mixed with water, the wage I usually get is 3,000 rupiahs. If the price of rubber goes up we are paid 3,000 rupiahs anyway".

Interview with Takko (52 years old)

Rubber plantation is a sector that has the potential to be developed in order to increase community income and also be able to support the economy in Bulukumba Regency. Bulukumba Regency is one of the rubber-producing areas in Indonesia which has a fairly large planting area. The area of Bulukumba District has an area of $171.3 \mathrm{~km} 2$ with a population of 56,354 people. The development of the rubber plantation area in Bulukumba Regency in 2011-2013 experienced an increase, it was noted that the rubber plantation area of Bulukumba Regency in 2011 which reached 1,784.94 Ha increased to 2,146.84 Ha (BPS Bulukumba, 2020). The increase in the area of rubber plantations has an impact on rubber production in Bulukumba Regency, South Sulawesi, as noted above. People who work as 
Fajrin Kasdi, Transformation Of Social And Economic Livelihoods Of Rubber Farmers.

rubber farmers and get a salary from their business to meet family needs. With an increase in income or salary every year, it will further create prosperity for the rubber farming community.

Fitri and Suwarto (2016) suggest that increasing the knowledge and skills of rubber cultivation techniques and other things that support rubber farming needs to be pursued so that it will be able to increase the productivity of smallholder rubber. Income is the number of assets at the beginning of the period plus all the results obtained during the period, not just consumption.

Riska (2011) in her research which investigated the factors that influenced the increased production of rubber trees in the plantation of PT. Lonsum in Bulukumba Regency found that what affects rubber production is very much influenced by the production of rubber plants. Likewise, with Nasamsir (2008), natural rubber (Hevea brasiliensis) is a commodity that is widely developed in the world, especially by the largest natural rubber producing countries including Thailand, Indonesia, and Malaysia. The main objective of natural rubber development is to produce latex and its clots. Latex and its clots are the main raw materials for agriculture-based industries to produce rubber-based products such as tires, rubber boots, rubber gloves, balloons, and other rubber products. The low quality of rubber processing materials shows that improving the quality of rubber in Indonesia must start at the level of farmers (smallholder rubber farmers).

\section{THEORETICAL REVIEW}

Adam Smith in Skousen (2015) views the position of the main means of production land is very important for the economy because the land is a source of production. Adam Smith recognizes private ownership in every commodity. However, Smith emphasized more on the divisions of labor in order to further increase productivity. Smith's divisions of labor try to bring out the character of individualism and make humans appear as programmed machines, regardless of the time efficiency that they cause. Smith considers the specific use of the plot of land as a procurement cost in terms of alternative opportunities, whereas in macroeconomic theory the distribution of land as a whole is seen as an acquisition rather than an alternative use. The increase in the income of the landlord class in national income reflects the advancement of the trade from the agricultural sector (Evensky, 1993).

However, the above theory is opposed by Ricardo in Newman (2006), according him, there are three groups of people in economic society, namely the capitalist class, the 


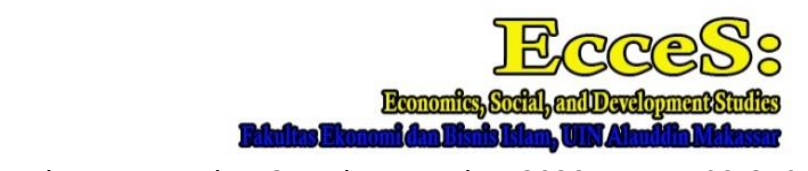

Volume 7 Number 2 Ed. December 2020: page 198-219 p-ISSN: 2407-6635 e-ISSN : 2580-5570

landlord class, and the labor class. The capitalist class is the most important group because this group can increase national income, it is because the capitalist class who leads a production always seeks profit and reinvesting its income. The next group is the landlord class who owns the land. This group does not produce anything like the capitalist class, but this group owns land which is not owned by capitalists, the landlords will only lease their land to the capitalist class for profit. The last is the group of workers who have the largest number of people compared to other groups. This group does not have the means of production, only has labored, and converts raw materials into commodities of the sale value. Labor groups are usually considered low in the social structure because they are poor and uneducated. However, this group has a very important role in producing. The course of production depends on the working class.

The theory above was then synthesized by a socialist thinker named Karl Marx. Marx in Setiawan (2015) argues that the main means of production in economic activity is land. Moreover, the land must be owned communally or collectively (social ownership). In the historical development of society, Marx shared the history of change in society. Starting from primitive communal, people in this phase still used simple tools of work and the way the people at that time survived by hunting and gathering. Economic activities are carried out in a collective way and there is no private ownership of land and others, in this era the characteristic of the community is nomadic. Entering the capitalistic phase, where the land is controlled by the bourgeoisie. And the next stage is the phase of Marxist socialism, where the land will be taken over from the bourgeoisie to be redistributed to the proletariat, to be used as much as possible for the welfare of the lower class society (Greenhill and Wilson, 2006).

The natural wage theory is also called the normal wage theory. This theory was put forward by Ricardo in Skousen (2015) which divides wages into two types, namely natural wages and market wages. How do natural wages differ from market wages? Natural wages are wages whose amount depends on the forces of demand and supply of labor in the market. Natural wages are wages that are used as a reference so that workers live properly. What workers actually receive is the market wage. If the market wage is higher than the natural wage, prosperity will increase, so that the marriage rate will also increase. The marriage rate has increased due to the ease with which workers can get the costs of getting married. Furthermore, the birth rate will increase. As for the mortality rate, it actually 
Fajrin Kasdi, Transformation Of Social And Economic Livelihoods Of Rubber Farmers.

decreased, due to increased family health and welfare (Rioux, LeBaron, and Verovšek, 2020).

The increase in births causes the number of workers to increase so that the supply of labor will also increase. This increase or increase in the supply of labor causes the market wage level to fall close to or even below the natural wage. This occurs because the supply of labor is higher than the demand for labor. As wages decline, the marriage rate decreases, and the birth rate decreases. On the other hand, the death rate has actually increased. Furthermore, the supply of labor is reduced so that it has an impact on increasing market wages. And so on and the situation will repeat itself again as explained above. This theory contradicts the iron wage theory, this theory put forward by Lasalle in Nova (2017) according to him, the wages received by workers are minimum wages. so that entrepreneurs can get the maximum profit. Workers are in a weak position so they can't do anything and are forced to accept the wages. Such conditions are called iron wages. Furthermore, to improve their lives, workers are advised to establish production cooperatives so that they are released from the grip of iron wages. This theory is supported by the discrimination wage theory. This theory states that the wages given to workers are not the same, but are deliberately differentiated (discrimination) for each worker. Wage differences are influenced by several factors, including gender, race (color), and type of work.

John in Bandiera, et. all (2017) considers that the wages that should be paid to workers are in accordance with their productivity. If workers are more productive and add more value to the company's profit in the long run, their wages tend to rise. If wages rise in industry, the competition will force employers to raise wages, and hence "wages tend to equal the marginal product of labor" or what is paid to the last worker. In competition, most workers will be paid according to what they contribute to society, and secondly, workers who do not show their productivity will also benefit from the marginal productivity of workers in general. There should be no monopoly power and big business trying to exploit workers by pressing wages below their marginal product. A competitive environment in the labor market and industry is essential for legitimate wages and social justice.

\section{METHODS}

The type of research used is qualitative, which is descriptive in nature, while the approach used is an economic ethnographic approach. Where researchers try to explore the 
livelihoods of rubber farmers and are directly involved in the daily activities of the informants, to understand the real-life of rubber farmers. Researchers, in this case, are in direct contact with informants directly and objectively, to minimize bias that occurs in understanding the livelihoods of rubber farmers. The research location is in Batulohe Village, Bulukumpa District, Bulukumba Regency. Data collection was carried out in this study by means of interviews, observations, and document studies, which were carried out comprehensively, to obtain a portrait of data that was rich in the cases studied. This case study approach raises the socio-economic conditions of rubber farmers as material for case studies related to village development from various perspectives.

In analyzing the socio-economic impact of this research, the things that will be observed are the structure of land ownership, the level of wages of rubber workers, educational conditions and access to information on rubber farmers, and the value chain of the rubber trade in Batulohe Village. In addition, the data in this study were obtained from book reviews, journals, BPS statistical data, and interviews conducted at the research location, which had gone through a triangulation process.

\section{RESULTS AND DISCUSSION}

Table 1

Area and Production of Smallholder Plantation Plants by Type Plants in Bulukumpa District 2018

\begin{tabular}{lcc}
\hline \multicolumn{1}{c}{ Types of Plants } & $\begin{array}{c}\text { Area } \\
\text { (ha) }\end{array}$ & $\begin{array}{c}\text { Production } \\
\text { (ton) }\end{array}$ \\
\hline Rubber & 2 & 3 \\
\hline Coffee & $1.381,00$ & 456,9 \\
\hline Coconut & 840,00 & 176,75 \\
\hline Pepper & 139,00 & 51,45 \\
\hline Cocoa & 455,00 & 56,06 \\
\hline Tobacco & $1.183,0$ & 823,19 \\
\hline Nutmeg & 11,00 & 4,00 \\
\hline Clove & 272,00 & 15,03 \\
\hline Cashew & $1.559,0$ & 125,90 \\
\hline
\end{tabular}

Source: BPS Kabupaten Bulukumba, 2019. 
Fajrin Kasdi, Transformation Of Social And Economic Livelihoods Of Rubber Farmers.

Bulukumpa District is known as one of the areas with high land area and high rubber production, apart from Kajang and Ujungloe Districts.

\section{Land Ownership Structure in Batulohe Village}

Batulohe Village as one of the centers for community rubber production contributes to rubber farmers materially to be used to meet their daily needs. The large area of land will certainly greatly affect the increase in production. Rubber farmers in Batulohe Village generally already have land to work on, although they vary in area, ranging from $1 / 2$ hectare to 3 hectares. As stated by Rahman, a rubber farmer who owns 3 hectares of rubber land, the amount of production per harvest reaches 25 to 30 kilos $(\mathrm{Kg})$ per day.

"The people here own land on average, but the amount of land varies. If the harvest depends on the weather, if it is good the usual yield is $20 \mathrm{~kg} /$ day, but if the weather is like now the rainy season will be 1 week before we harvest again. Let's imagine if 1500 trees are harvested because 1 hectare is an average of 500 trees. So a lot of the results are just stored in the warehouse until the seller comes to take it"

Interview with Rahman (32 years old)

However, according to other sources, the opinion was different from what was conveyed by Rahman. Mr. Muh Jafar, for example, said that this is not always the case but it depends on the density of the trees and the quality of the rubber trees. If the quality of the D4 trees will have implications for the amount of rubber production which is also not small. The rubber land he owns is not managed alone, but by employing other people to manage the rubber plantation he owns.

"It depends on the density of the trees, for example, I have 1 hectare of land but the number of rubber trees is around 1000, so there will be lots of results when harvested. The quality of the trees is also seen, there are D2, D3, and D4, if D4 there are also many results. If here the average company using D4 is PT LONSUM. If my garden is managed by someone else with a profit-sharing system.

Interview with Mr. Muh Jafar (65 years old)

The father, who used to be a teacher, admitted that the amount of rubber harvested could reach $50 \mathrm{~kg} / 3$ days after being stored in the warehouse for sale to village traders who usually came once a week. As mentioned above, not all communities who have rubber gardens manage themselves, usually, they employ other people who already have experience in managing up to tapping and the harvest will be shared with rubber plantation owners, this will be discussed further in the sub-discussion. 


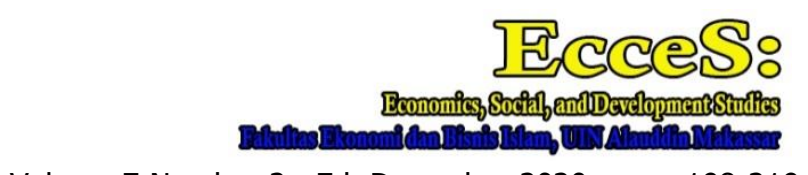

Volume 7 Number 2 Ed. December 2020: page 198-219 p-ISSN: 2407-6635 e-ISSN : 2580-5570

However, another rubber farmer named Ancu confirmed what Rahman had said. According to him, the size of the land will have a significant effect on rubber production. He further said that using D4 seeds is relatively expensive compared to other seeds, so it is included in the production costs.

"The people here have 3 hectares, some have less than one hectare. For those who have a lot of lands, the results will also be harvested. Normally it's 500 trees 1 hectare. If you use D4 seeds it's good but most farmers here use seeds. D3 because D4 seeds are also a bit expensive so the price is the same if we usually harvest 200 kilos/month. Depending on the weather too "

Interview with Ancu (35 years old)

As well as being a rubber farmer, Ancu also has a side job as a chicken farmer. He said that only expecting from the sale of rubber is not enough to meet his daily needs, especially if the price of rubber is relatively volatile. In simple terms, it can be concluded that, in Batulohe Village, rubber farmers already own land even though there are some farmers whose land is still under one hectare and the most are three hectares. This illustrates that the inequality of land tenure structures in Batulohe Village is still relatively normal because there is no very significant disparity in land tenure. This is in line with Morten's (2019) findings that farmers who migrate and work temporarily in India and then work as farmers, indicating that farmers obtain agricultural land management rights distributively and there is no inequality in land ownership. This contradicts the findings of Webb (2015) that capitalism works massively for the livelihoods of cocoa farmers in Southeast Sulawesi, Indonesia. Where land ownership is very unequal and tends to be controlled by capital owners.

\section{Wage Level of Rubber Workers in Batulohe Village}

Wages are an important instrument for improving farmer welfare. Wages or salaries are closely related to the result of various forms of services provided and provided by workers to employers or their employers in order to meet their daily needs. The level of wages is closely related to the productivity of workers or the level of commodity prices.

In Batulohe Village, rubber workers usually have land to work on, be it agricultural lands such as chilies, peppers, and other vegetables, some also have rubber land even though the area is less than 1 hectare. As experienced by one rubber worker in Batulohe 
Fajrin Kasdi, Transformation Of Social And Economic Livelihoods Of Rubber Farmers.

Village named Saparuddin. He admitted that if the wages given depend on the price of rubber if the price of rubber has increased, the wages given will also increase.

"I used to work for a company (PT Lonsum). Now I work for other people's rubber trees, besides that, I also farm behind my house. If the wages are divided evenly after the harvest results are sold to traders. For example, now the price of rubber is 7000 Rupiah per kilo, so I get 3500 per kilo, but now the price of rubber is pretty good, back then the price of rubber was 4,000 Rupiah so what I get is a little too "

Interview with Saparuddin (39 years old).

The laborers who work on other people's rubber fields start working from the nursery until the rubber trees are ready to be harvested. As for what is usually done during the maintenance process starting from replacing the wire, shower, and container (bowl) attached to the rubber tree if it starts to break or break, rubber workers are also tasked with providing fertilizer to the rubber tree, normally fertilized every 6 months once and also given poison if there are pests that can damage the quality of rubber, the amount of fertilizer also varies depending on the area and number of rubber trees. The price of all the needs for rubber tree maintenance ranges from 2,500,000 Rupiah for 3 months to 6 months depending on the number of rubber trees.

"There are several tools and maintenance materials that are changed, for example, the bowl is replaced when it starts to break, the causes are also various. Usually, if it's been too long the bowl is not covered, usually, because it is often exposed to the hot sun. The shower is also replaced if it starts to break so that if you want to tap (tapping) everything can go into the bowl you fall down. You also have to give the fertilizer when it's been 3 months so that lots of rubber is harvested ".

Interview with Herman (31 years old).

However, different information was conveyed by Daeng Takko, a worker who has worked for 30 years, revealed that if the wages given to rubber workers were relatively constant even though the price of rubber had increased, he admitted that while he was working on other people's rubber land his income remained even though the price of rubber increased

"I have been working for 30 years, initially I worked at PT LONSUM but because of the influence of age, I quit. Now working on rubber land owned by someone else, I get 2500 per kilo from the first since the price was 6,000 Rupiah, now the price of rubber is 7500 Rupiah because the price has indeed gone up and down ".

Interview with Daeng Takko (58 years old). 


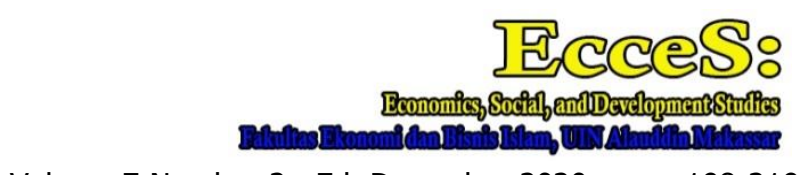

Volume 7 Number 2 Ed. December 2020: page 198-219 p-ISSN: 2407-6635 e-ISSN : 2580-5570

Daeng Takko's statement was confirmed by a rubber worker named Herlin, apart from being a rubber worker Herlin also worked as an employee at PT.LONSUM in Batulohe Village, he revealed that rubber workers usually work on relatively large land because the land they own is not sufficient for their needs. for a month, then he also works for someone else, he continues the number of wages does not depend on the price of rubber which has increased.

"The rubber workers here mostly own land, but it is narrow or work for companies, so they also work for other people to increase their income. If the problem of the price of rubber goes up and down, you are still, if the price goes up, the wages that go to the workers should also go up anyway, but I got 3000 Rupiah/kilo, now the price for rubber is 7500, back then the price of 6000 was the same. 3000 Rupiah, fortunately, this is a salary from the company so that you can support your family at home ".

$$
\text { Interview with Herlin (32 years old) }
$$

Herlin is just one of the workers at PT LONSUM who also works as a laborer on someone else's rubber land. This man who supports 3 children has worked for PT LONSUM for 5 years. According to him, there are many people in Batulohe Village who work for PT LONSUM because the average community is still low educated, moreover, the company does prioritize the Village community to work at PT. LONSUM as a manual laborer. He added that rubber workers usually work on other people's rubber land which has a large area of land and the landowner has other businesses so they employ people to manage the rubber land.

According to the statements of several informants above and by using the triangulation technique, the wages given to rubber workers who work on land owned by others are relatively constant, even though the price of rubber has increased. The wages given to rubber workers should also increase according to the price of rubber. The wages earned by rubber workers who work on 2 hectares of land are IDR 3000 / kilo with a total production of 400 kilos/month and a rubber price of IDR 7,500. So the sales for one month are Rp. 2,960,000. The bad wage that rubber gets for one month is IDR 1,200,000 and what the landowner gets is IDR $1,760,000$.

It can be concluded that the wages given by landowners to rubber workers are unfair and proportional because the amount earned by landowners is greater than what smallholders give. If you want to compare it with the Minimum Wage for Work (UMK) in the Regency / City of South Sulawesi (Sulsel), then the wages for rubber farmworkers in Batulohe Village are very far below the UMK in the Regency / City of South Sulawesi, which 
Fajrin Kasdi, Transformation Of Social And Economic Livelihoods Of Rubber Farmers.

is IDR 2,860,382 in 2019. This is in line with Caton (2015) which describes the livelihoods of farmers in Punjab, India from 1850-1900 who experienced exploitation, they received unreasonable wages, which on average worked as farmers. Landlords tend to be wealthier and get richer over time. This contradicts the findings of Bagger and Lentz (2019) in a low wage labor market that hardly occurs in developed countries, where farmers get decent wages. Low wages occur in situations of mismatch in the labor market.

\section{Educational Level of Rubber Farmers}

Good education needs to be continuously improved to improve the condition of people who are still below the poverty line. This also applies to farmers in optimizing their production. However, in the case of rubber farmers in Batulohe Village, the knowledge gained from formal education does not guarantee that they will increase rubber production without having skills and direct experience in managing rubber. As stated by one of the rubber farmers in Batulohe Village named Mrs. Rukiyah. Mrs. Rukiyah has been a rubber farmer for decades and her last education was only at the elementary school level, but she can produce 20 kilos of rubber per day with a land area of 0.5 hectares with 200 rubber trees, in an interview with her researcher. reveal some important things.

"For a long time, I worked as a rubber farmer here, since the 90s I was a farmer, at first I could manage it myself because many families worked rubber, so I saw how to work and then follow the method of cleaning, giving fertilizer until it is harvested. My school, I only went to elementary school because this is not a high school, the important thing is that I have seen it once, it can be done because there are a lot of teachers who are also working.

Interview with Rukiyah (50 years old).

According to Mrs. Rukiyah, who also works as a trader, the level of education at formal schools does not give any significance to the resulting rubber productivity. This happens because in the activity of managing rubber, it does not really require special skills or specific competencies to be able to manage it, which is probably the most requires a special technique is when doing suction which not everyone can do but requires a special technique and is usually done by people who already have experience in managing rubber.

Ibu Hajirah also shared something similar with Rukiyah. According to this middleaged mother, the level of education has absolutely no effect on the amount of rubber harvested, but she puts more emphasis on the experience and the area of rubber land she owns. He even admits that he never received formal education. Ibu Hajirah owns 0.5 


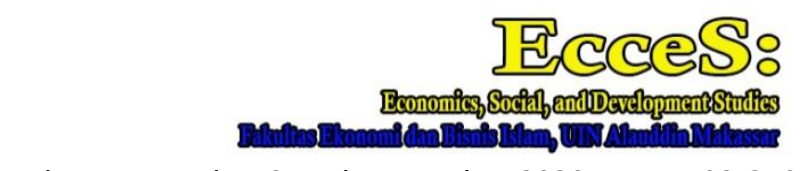

Volume 7 Number 2 Ed. December 2020: page 198-219 p-ISSN: 2407-6635 e-ISSN : 2580-5570

hectares of land and usually produces approximately 100 kilos/month using 1 sack of fertilizer, and even then is given fertilizer only once a year so that the rubber trees can continue to produce rubber sap.

"I never went to school. On average, those who work in junior high schools at the highest school can also work in rubber, the important thing is that everyone can work with fertilizers, except if the company requires a high school".

Interview with Hajirah (52 years old)

The information from Mrs. Hajirah and Mrs. Rukiyah at least represent the answers of several informants who answered with the same thing that the level of formal education is not really related to rubber productivity due to the reasons mentioned above.

In general, it can be concluded that the level of formal education for rubber farmers is still low, although it is well known that education is indeed one of the determinants in developing the abilities or skills of every human being, however, in terms of rubber management, formal education does not really have an impact on increasing rubber production. The same answers the researchers also got from several respondents who were interviewed researchers, proves that managing rubber, it does not have to require specific skills by rubber farmers, but experience and land area factors are the main basis needed by rubber farmers in managing and developing rubber production.

So, Adelmen (1975), Adelmen and Robinson (1989), Carnoy, et.al (2012), Gregorio and Lee (2002), Psacharopoulos (1977), Sylwester (2002), and Ram (1989) assumes that formal education is a strategic step to overcome poverty, it does not run linearly with the reality that occurs in Batulohe Village, because the experience factor is a very determining factor in managing rubber in Batulohe Village. In contrast to the findings (Arif, 2017) that agrarian transformation runs strategically if there is no formal education and adequate knowledge and innovation for farmers.

\section{Access to Information}

Access to information in the agricultural world is also important in determining how rubber products get a fair price for the sake of increasing the welfare of rubber farmers. Information on prices that are not suitable will certainly harm farmers economically because they are not in accordance with what is being done in rubber plantations which in fact benefits those who know information about prices. The monopoly of information, especially 
Fajrin Kasdi, Transformation Of Social And Economic Livelihoods Of Rubber Farmers.

prices, is a problem that is being faced by farmers in several regions in Indonesia. There are parties who know the information and do not distribute it to farmers, making farmers the losers of the problem.

This is where the role of the government should be as the party that has the responsibility to solve the problem of lack of information on prices. The government with all its institutions should provide accurate information to farmers so that agricultural commodities can be sold at proportional prices and do not harm farmers. Mr. Hasan, for example, as one of the rubber farmers, said that the price of rubber was determined by village traders who bought farmers' rubber for an indefinite period of time by looking at the quality of rubber, usually, rubber traders would visit each farmer's house to buy it.

"Usually here, when we harvest, we don't sell it right away, but we wait for the traders who come using a new car at the weighing station, they are usually asked to say that the price of rubber is the same as the price, see also the quality of the rubber if there is a lot of water mixture, especially if the rainy season means it's cheap or available. the mixture of sand or stones in the rubber also drops, that's the price, if the prices are all flat, there's no difference here, it's different there is also different, it's all the same".

Interview with Hasan (40 years old)

Hasan said that information on rubber prices is usually seen from the quality of the rubber, he also added that if the rubber has a soft texture, the price will also decrease. Other information the researchers also got from a rubber trader named Sappewali. He considers that the change in rubber prices follows the trend of global rubber prices and also the rupiah exchange rate against the dollar. If in the global market the price of rubber increases, then that is also used as a benchmark for rubber prices at the local level.

"The price of rubber follows from the price of rubber outside the country, if the price of rubber outside of the country rises, that is what we use here, the same as all that if the value of the rupiah rises again, the price of rubber also increases, usually traders from that city are know, but that's the case. determined the price of rubber, we just follow ".

Interview with Sappewali (42 years old)

The explanation above contrasts with what was conveyed by Mr. Hasan, who considered that the ups and downs of rubber were seen from the quality of the rubber. Sappewali considers that the global rubber trade and the rupiah exchange rate are the factors that determine the price of rubber. This information is brought by traders from Makassar before being sent to Java and Sumatra to be managed into commodities that can be purchased by the general public. 


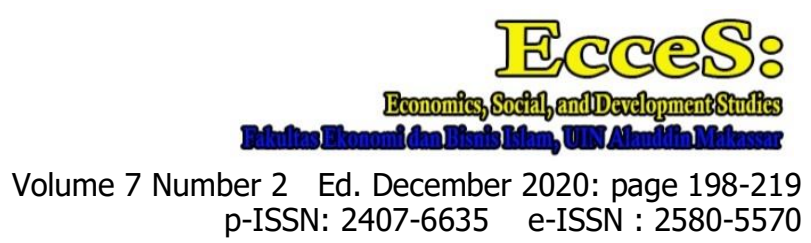

There is also an opinion from one of the rubber farmers named Ambo Nas who affirms Sappewali's statement that the price of rubber is determined by the rupiah exchange rate. According to him, the price of rubber does fluctuate, but not in terms of quality because the quality of rubber from Bulukumba Regency is of good quality when compared to rubber plantations in other regions in Indonesia.

"The price of rubber is seen from its rupiah value, because if we want to compare the quality of rubber in Bulukumba with other areas, it is better here, so the price of rubber usually does not go down quickly unless the value of rupiah falls again compared to the dollar, here the quality of the rubber is wrong. one of the best in the world".

Interview with Ambo Nas (44 years old)

The statement from Ambo Nas is a statement that justifies Sappewali's opinion that the price of rubber is determined by the global rubber trade trend and also the relatively fluctuating rupiah exchange rate, which makes rubber prices also tend to fluctuate. However, information and price determination are entirely determined by traders, farmers can only predict the price of rubber with information obtained from traders that are not necessarily true.

Market information or rubber prices are obtained from the knowledge of global rubber prices obtained from traders. Based on the information from the informants, we can judge that there is an imbalance in the information obtained by the farmers because it is monopolized by traders, both at the village and city levels, which ultimately causes losses to farmers.

So, Amartya Zen's theory as expressed by Alkire (2007), Frediani (2010), Martens and Bastiaanssen (2019), Samat, et.al (2012), argues that poverty occurs due to the absence of information on the society, in line with the facts that occurred in Batulohe Village because information on prices was monopolized by traders at both the village and city levels. However, it is different from the findings of Lucas (2004) who found that advanced agricultural areas supported by human capital intensive will have access to distributive information on the right to work and fulfillment of needs.

\section{Rubber Trade Value Chain in Batulohe Village}

The market chain is a chain that is used to describe a number of networks that connect all related actors and transactions in the movement of trade goods from agriculture 
Fajrin Kasdi, Transformation Of Social And Economic Livelihoods Of Rubber Farmers.

to consumers. Market chain analysis is used to identify and explain all points in the chain. The series of processes in the commodity chain creates linkages between activities and actors that provide added value, space, in this case, is closely related to the location in the market chain which is illustrated by the movement of agricultural commodities from one location to another.

The market chain that occurs in an agricultural activity will have implications for a system that makes the parties who produce agricultural products, in this case, the farmers, become subordinated and disadvantaged parties. Batulohe Village as an area where the community works as rubber farmers is part of the subordinated party. Farmers who should be the beneficiaries in agricultural activities are increasingly degraded due to the market price chain that occurs.

For example, what was expressed by one rubber farmer named Jusri. Jusri said that the rubber he harvested would be sold to one of the village traders who visited each house to buy rubber at a price set by the village trader, which would later be sold to traders from the city.

"When the rubber is harvested, wait until it arrives, the regular mobile traders, some of them from here, come from Kajang or from other villages to come here to collect rubber at every house that has rubber and is ready to sell. Later, when it has been taken, it will be taken to the warehouse, the new traders will be sold to traders from the city.

Interview with Jusri (33 years old)

Jusri's statement above provides preliminary information that the rubber produced will be purchased by traders from the village who will be brought to traders from Makassar who will then be sent to the processing industry. However, Jusri's statement has not provided information about the actual price given by village traders to traders from Makassar City. Researchers got information on the price of rubber when conducting an interview with Mrs. Hj Andi Darmawati as one of the traders in Batulohe Village. He said that after the rubber was bought from farmers in each house, it would be brought to the warehouse to wait for the traders from the city to buy it.

"Now that rubber costs 7,500 Rupiah, it is bought at every rubber farmer's house, so when it's harvested, usually every 2 or 3 days they come to each house to buy rubber, just take it to the warehouse while waiting for traders from the city to buy it, every 3 or 5 days the merchant come using a container car. Now, because the price is 7,500 we sell 8,000 to 8,500 / kilo, usually, the rubber purchased here is sent to Surabaya".

Mrs. Hj Andi Darmawati (55 years old) 
According to information from Jusri and Mrs. $\mathrm{Hj}$ Andi Darmawati that the trade chain in Batulohe Village only involved a few actors, namely farmers as rubber suppliers, village traders, and city traders. When the researcher asked how much he sold when he arrived in Makassar, he admitted that he did not know the details. The same thing, the researcher also asked a trader who came from Makassar named Anto about the price of rubber when it was shipped outside the island, he also did not know for sure.

"I also don't know about the price issue, because my job is only to take rubber and it just brought it to Makassar".

$$
\text { Interview with Anto (28 years old) }
$$

Figure 1

The Trade Value Chain From Rubber Farmers To The Processing Industry Batulohe Village, Bulukumba Regency

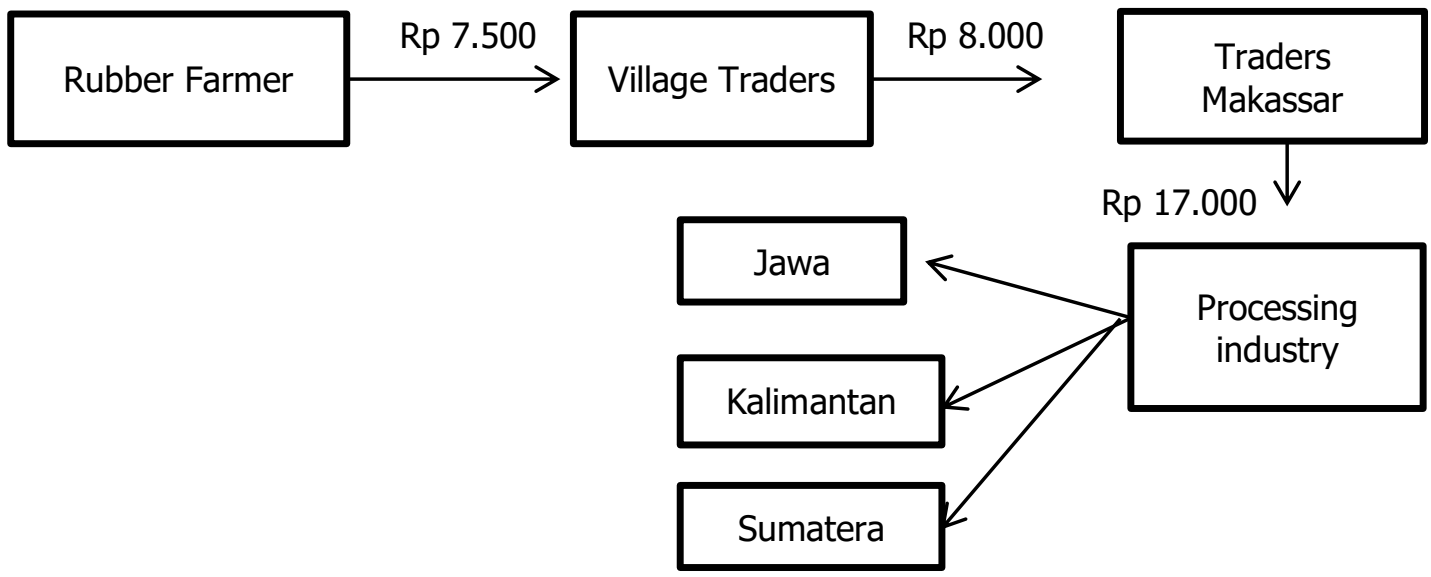

So, the rubber trade chain in Batulohe Village does not involve such a complex network, but only involves a few actors. In simple terms, it can be seen from the image of the production chain. From the first picture above, you can see the chain of movement of rubber commodities from farmers to processing industries. Initially, rubber farmers sold their rubber to village traders for IDR 7,500 / kilo, then village traders sold them to traders from Makassar at IDR 8,000 / kilo and Makassar traders sent them to processing industries on the islands of Java, Kalimantan, and Sumatra for IDR 17,000 / kilogram.

The movement of the trade chain from rubber farm laborers to the processing industry. Farmworkers earn Rp. 3,000 / kilo and rubber owners get Rp. 4,500 from sales from village traders at Rp. 7,500 / kilo, village traders sell them to Makassar traders for Rp. 
Fajrin Kasdi, Transformation Of Social And Economic Livelihoods Of Rubber Farmers.

8,000 / kilo, from Makassar traders then sold to processing industries in three islands, namely Java, Kalimantan, and Sumatra at a price of IDR 17,000 / kilogram.

Figure 2.

Value Chain of Trade from Farmers to the Rubber Processing Industry in Batulohe Village, Bulukumba Regency

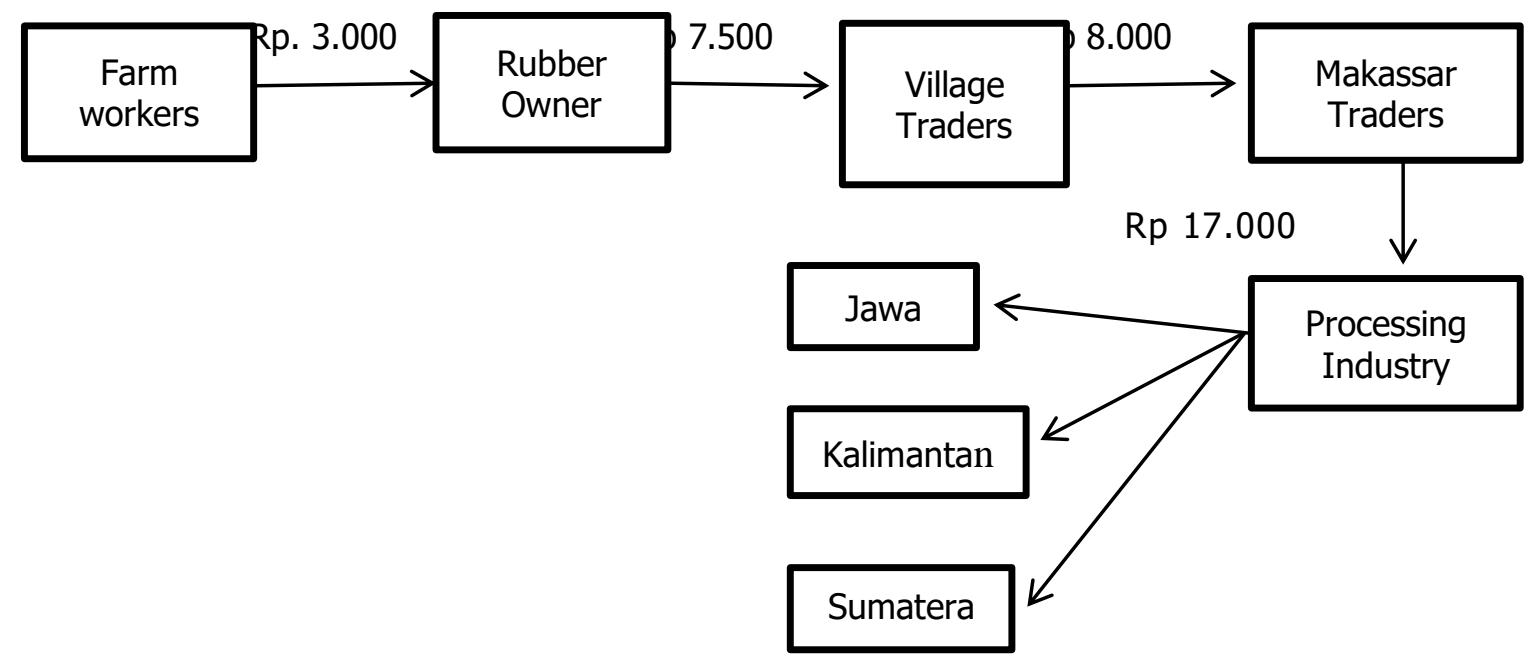

\section{CONCLUSION}

Rubber seems to be a very promising commodity materially and helps farmers in Batulohe Village to improve their welfare. Specifically, the conclusions of this study are further elaborated. (1) On average, rubber farmers already own land to produce, the imbalance in land tenure structure can be said to be relatively normal because there is no very significant disparity in land tenure. (2) In fact, the level of production is not accompanied by an increase in wages for agricultural laborers, the wages given by land owners to rubber workers are unfair and proportional because the amount obtained by landowners is greater than what is given by smallholders, even below the Provincial Minimum Wage. South Sulawesi, amounting to Rp. 2,860,382 in 2019. (4) Formal education as a strategic step to overcome poverty does not run linearly with the realities that occur, because the experience factor is a very determining factor in the success of managing rubber. (5) There is an imbalance in the information obtained by farmers regarding market information or the price of rubber because it is monopolized by traders at both the village and city levels, which ultimately results in losses to farmers. (6) There is a network of actors that connects commodity transactions to consumers, which results in losses incurred by 
farmers. To improve the livelihoods of the poor in rural areas, a big push intervention policy from the government is needed, so that there will be a redistribution of fiscal allocations to the poor and an improvement in livelihoods and income.

\section{REFERENCES}

Adelman, I., 1975. Growth, income distribution, and equity-oriented development strategies. World Development, 3(2-3), pp.67-76.

Adelman, I. and Robinson, S., 1989. Income distribution and development. Handbook of development economics, 2, pp.949-1003.

Alkire, S., 2007. The missing dimensions of poverty data: Introduction to the special issue. Oxford development studies, 35(4), pp.347-359.

Arif, N. I. N. 2017. Enlarging Workers Reserves: " Demographic Bonuses" and State Political Economy, 5415, Pp. 187-200.Doi: 10.1086/379942.

Asrina. 2013. Analisis Produksi Karet Terhadap Pendapatan Ekonomi Masyarakat Dalam Perspektif Islamdi Kabupaten Bulukumba (Studi Pada Perkebunan Karet PT. Lonsum). Uin Alauddin Makassar.

Aswandi, K., 2019. Silang Sengkarut Pembangunan Berkelanjutan Perkotaan Dalam Pusaran Kapital (Studi Kasus: Megaproyek Reklamasi CPI Makassar). EcceS (Economics, Social, and Development Studies), 6(1), pp.1-17.

Bagger, J. and Lentz, R. (2019) 'An Empirical Model of Wage Dispersion with Sorting', Review of Economic Studies, 86(1), pp. 153-190. doi: 10.1093/restud/rdy022.

Bandiera, O., Burgess, R., Das, N., Gulesci, S., Rasul, I., \& Sulaiman, M. 2017. Labor Markets and Poverty in Village Economies. The Quarterly Journal of Economics.

Badan Pusat Statistik (BPS).2020. Kabupaten Bulukumba.

Badan Pusat Statistik (BPS).2019. Kabupaten Bulukumba. 
Fajrin Kasdi, Transformation Of Social And Economic Livelihoods Of Rubber Farmers.

Budiman Achmad, Dian Diniyati, Eva Fauziyah dan Tri Sulistyati. 2015. Analisis Faktor-Faktor Penentu Dalam Peningkatan Kondisi Sosial Ekonomi Petani Hutan Rakyat Di Kabupaten Ciamis. Jurnal Penelitian Hutan Tanaman Vol. 11 No. 3, April 2015: 63-79.

Caton, B. .2015. The Transition from Animal Capital to Land Capital in Colonial Punjab, 1850-1900', Capitalism, Nature, Socialism, 26(3), pp. 64-72. doi: 10.1080/10455752.2015.1070362.

Carnoy, M., Loyalka, P. and Androuschak, G., 2012. Does Expanding Higher Education Equalize Income Distribution? The Case of the BRIC Countries. WP REAR, University of Stanford.

Erwin, Kharisma. 2014. Rantai Pasar Komoditas Pertanian Dan Dampaknya Terhadap Kegiatan Perdagangan Komoditas Pasar Projo. Jurnal Wilayah Dan Lingkungan Volume 2 Nomor 1, April 2014, 25-42.

Evensky, J. 1993. Retrospectives: Ethics and the Invisible Hand', Journal of Economic Perspectives, 7(2), pp. 197-205. doi: 10.1257/jep.7.2.197.

Fitri Gumayanti, Suwartono. 2016. Pemupukan Tanaman Karet (Hevea brasiliensis Muell Arg.) Menghasilkan di Kebun Sembawa, Sumatera Selatan. Bul. Agrohorti 4(2) : 233-240 (2016).

Frediani, A.A., 2010. Sen's Capability Approach as a framework to the practice of development. Development in practice, 20(2), pp.173-187.

Greenhill, A. and Wilson, M. 2006. Heaven or hell? Telework, flexibility, and family in the esociety: A Marxist analysis', European Journal of Information Systems, 15(4), pp. 379-388. doi: 10.1057/palgrave.ejis.3000632.

Gregorio, J.D. and Lee, J.W., 2002. Education and income inequality: new evidence from cross-country data. Review of income and wealth, 48(3), pp.395-416.

Lucas, R. E. 2004. Life earnings and rural-urban migration', Journal of Political Economy. doi: $10.1086 / 379942$. 
Nasamsir. 2008. Respons Pertumbuhan Bibit Karet (Hevea Brassilliensis Muell.Arg) Asal Okulasi Terhadap Aplikasi Pupuk Npk (20-6-6) Berbeda Konsentrasi. Jurnal Ilmiah Universitas Batanghari Jambi Vol.8 No.2 Juli 2008.

Newman, Michael. 2006. Sosialisme Abad 21: Jalan Alternatif Atas Neoliberalisme. Cet. I; Yogyakarta: Resist Book

Nova, Yuliana. 2017. Pengaruh Tingkat Upah Terhadap Kinerja Buruh Dalam Perspektif Ekonomi Islam (Studi Kasus Pada CV Tedmond Fibre Glass). Jurnal IImiah Vol.3 No.2 Agustus 2017.

Martens, K. and Bastiaanssen, J., 2019. An index to measure accessibility poverty risk. In Measuring Transport Equity (pp. 39-55). Elsevier.

Morten, M. 2019. 'Temporary migration and endogenous risk sharing in village India', Journal of Political Economy, 127(1), pp. 1-46. doi: 10.1086/700763.

Psacharopoulos, G., 1977. Unequal access to education and income distribution. De Economist, 125(3), pp.383-392.

Ram, R., 1989. Can educational expansion reduce income inequality in less-developed countries?. Economics of Education Review, 8(2), pp.185-195.

Riska. 2011. Faktor-Faktor Yang Mempengaruhi Meningkatnya Produksi Tanaman Karet Pada Perkebunan PT LONSUM Di Kabupaten Bulukumba. UIN Alauddin Makassar.

Rioux, S., LeBaron, G. and Verovšek, P. J. 2020. Capitalism and unfree labor: a review of Marxist perspectives on modern slavery', Review of International Political Economy. Routledge, 27(3), pp. 709-731. doi: 10.1080/09692290.2019.1650094.

Samat, N., Elhadary, Y.A.E., Hijles, F.M., Ghazali, S. and Sirat, M., 2012. Poverty and deprivation: using Geographic Information System in evaluating the accessibility of households to food retailers in Penang State, Malaysia. e-BANGI, 72 , , p.328.

Setiawan, Bonnie. 2015. Rantai Kapitalisme Global: Reorganisasi Fundamental Rantai Pasokan Global. Cet. I; Yogyakarta: Resist Book. 
Fajrin Kasdi, Transformation Of Social And Economic Livelihoods Of Rubber Farmers.

Sylwester, K., 2002. Can education expenditures reduce income inequality?. Economics of education review, 21(1), pp.43-52.

Skousen, Mark. 2015.Sejarah Pemikiran Ekonomi: Sang Maestro. Cet. V; Jakarta Prenadamedia Group.

Webb, C. (2015) 'Land's end: capitalist relations on an indigenous frontier, by Tania Murray $\mathrm{Li}^{\prime}$, Canadian Journal of Development Studies / Revue canadienne d'études du développement, 36(2), pp. 259-261. doi: 10.1080/02255189.2015.1041459. 